\title{
THE KENYA LAND LAW REFORM PROGRAMME - A MODEL FOR MODERN AFRICA?
}

\author{
By Margaret Rogers
}

In the past decade and a half, many independent African governments have devoted much time and thought to the reform of their land law. Land tenure both affects and is affected by economic, social and political change and there is little doubt that these have taken place in most independent African countries with varying degrees of rapidity. The Kenya Revised Development Plan 19661970 contains the statement ${ }^{1}$ that land is Kenya's most important resource and that economic development is contingent upon its intensive and productive utilization. It is not essential to change the system of land tenure in order to effect an improvement in land utilization; however, in most independent Commonwealth African countries, the land tenure system during the colonial period suffered various changes due to the introduction of alien land law concepts, either English, German or Indian. At independence, most African governments found themselves faced with a plural land tenure system under which part of the land was held under customary law and the remainder under some nonindigenous system. In Kenya, the presence of a relatively large number of white settlers had high-lighted, at an early stage, the problems of conflicting concepts of land tenure and the need for some form of rationalisation.

\section{Historical background}

The pattern of land tenure in Kenya to-day has been influenced largely by the developments in that part of Kenya occupied by the Kikuyu tribe, the largest of the tribes of Kenya. The Kikuyu lived in an area in which the rainfall was adequate and that combined with the high altitude of the land and a fertile soil, enabled the Kikuyu to practise mixed farming on an intensive scale. Each wife was responsible for her own fields and for the feeding of her children; as it was essential for her to grow the whole range of crops, needing different soils and conditions, she required several patches of land, some on the ridge tops and some in the valleys ${ }^{2}$. This meant that even within one single Kikuyu household, there was considerable fragmentation of land holdings and this was perpetuated by the practice of polygamy and the Kikuyu system of succession, by which the plots occupied by each wife, were, on her death, divided equally between her sons. This situation of uneconmic sub-division was further aggravated by the practice of 'shifting' agriculture whereby, after several years of continous cultivation, plots of land were allowed to lie fallow and apparently unoccupied. The stresses and strains within the Kikuyu land tenure system led ulitimately to the migration of small groups of Kikuyu to new territory. The Kikuyu were already encroaching on land claimed by other tribes before the arrival of the colonial administration and the supervening colonial policies added

1 p. 32 . Sorrenson, Land Reform in the Kikuyu Country - 1967, p. 4. 
greatly to the problems by granting parcels of apparently unoccupied and unclaimed lands to settlers and thus effectively sealing the boundaries in some areas of Kikuyu country. The population of that land occupied by the Kikuyu was growing fast and a serious land hunger situation arose.

Throughout most of the period of British rule in Kenya, it was the policy of the Colonial Office not to interfere with the customs and manner of life of the indigenous population. This was in contrast to the policy of the French governments of that time; the French policy was one of assimilation. The British policy on land holding was that native communal or tribal tenure should be preserved by creating land reserves for the indigenous population, set apart from the effects and influences of white settlement. The creation of those reserves was provided for by the Crown Lands Ordinance, 1915 but as the decision was not welcomed by some Kenya Colony and Protectorate Governors, it was not until 1926 that the bulk of those reserves were finally proclaimed.

The Colonial Office was concerned about the growing land problems in Kenya, particularly in Kikuyuland and in 1932, the Kenya Land Commission was appointed under the chairmanship of Sir Morris Carter. The Commission reported in 1933 and the settlement of the land problem was seen as one of segregation; the Europeans were to be confined to the European Highlands and except in one or two instances, were not to lose the land which the Kikuyu claimed had been taken from them. The tribe as a whole was to be compensated by additional land being added to the reserve. However, it was admitted that an estimated 110,000 Kikuyu, one fifth of the population of the tribe, were already living outside the reserve and the Commission concluded that as additional good agricultural land was not available, the ultimate solution was to improve the system of agriculture so that the available land could support more people.

Little was done to implement any recommendations of the Commission in the few years before the Second World War. War-time conditions brought a rapid change in the emphasis on cash-cropping and many farmers realised for the first time, the importance of land as an economic asset. This led to a demand from some African farmers for individual titles to land, inside the reserves, to compete with the security of tenure which the freehold or leasehold titles of the European farmers appeared to confer. The Colonial Office claimed to recognise at this stage, that in time, the communal tenure of the customary law would evolve in the direction of individual tenure. This claim was based on the much quoted passage by Sir F.J.D. Lugard ${ }^{3}$ in which he says:

"In the earliest stage, the land and its produce is shared by the community as a whole; later, the produce is the property of the family or individuals by whose toil it is won, and the control of the land becomes vested in the head of the family. When the tribal stage is reached, the control passes to the chief, who allots unoccupied lands at will, but is not justified in dispossessing any person or family who is using the land. Later still, when the pressure of population has given to the land an exchange value, the conception of property rights emerges and sale, mortgage and lease of the land, apart from its user, is recognised. These processes of natural evolution, leading up to individual ownership, may, I believe, be traced in every civilisation known to history."

3 Sir F. J. D. Lugard, The Dual Mandate in British Tropical Africa, 1923, p. 280. 
This passage has been challenged by Sorrenson ${ }^{4}$, who states that European observers, obsessed with the Lugard theory, have assumed that African land ownership was vested originally in the tribe but under the influence of European rule gradually evolved towards individual tenure. He goes on to show that in Kikuyu custom, the founder of a mbari or clan acquired what was in many respects an individual title to an estate; only on his death was a communal form of tenure created. Sorrenson's argument is that in Kikuyuland, the opposite process to that propounded by Lugard, was the rule. It seems clear that his challenge of Lugard's theory is justified but the ground on which he basis his challenge is somewhat shaky. The two writers were describing a different social structure but it is doubtful if the evolution of tenure described by Sorrenson differed greatly from that described by Lugard. In his writings on traditional tenure in a society similar to that described by Lugard, Elias says ${ }^{5}$ :

"Now, under the traditonal system, land could, in the first place, be acquired by an individual in four different ways:

1) A man might have taken some unappropriated land for himself;

2) He might, as a welcome stranger to a land-owning family, have been granted land by the head of the family, subject to the latter's right of reverter;

3) It might be an out-and-out gift to him of virgin land by a family having more land than it needed;

4) A man might, as a nember of a family, inherit a share of family land, ownership being still in the family...

. . But in every case, at the death of the originally grantee, the land would at once become family land in the hands of his children and relations."

It is hard to see how this situation differs from that described by Sorrenson as being the Kikuyu system. His challenge must be to Lugard's theory of "natural" evolution to individual tenure. The evolution could not be said to be natural if it were due largely to the influences of Western society! Lugard was basing his assumption on developments in the former British colonies; there, because of the political and economic influence of the former colonial power, the evolution was from communal to individual tenure but it may well not be evidently so in countries with a different political and economic structure; quaere the natural evolution in China from the commune system of holding to individual title to land. Sorrenson's quarrel must be with Lugard's bland assumption in regard to the future economic development of Africa. It was that assumption that led to his doubtful conclusion that the "natural evolution" of the major economic resource, i. e. land, was towards individual title.

\section{East Africa Royal Commission 1953-55 Report}

The Colonial Officer had dragged its feet on land policy decisions during the war but during the 1950's a number of factors arose which created the necessity for changes in the policy of the Kenya Government. One of the immediate causes of the Mau Mau emergency was land hunger in Kikuyuland.

4 Opp. cit. p. 9.

5 T. O. Elias, Nigerian Land Law and Custom (1953), p. 143. 
In 1954, the Swynnerton Plan for the development of African agriculture ${ }^{6}$ was submitted to the Kenya Government; the proposals contained in the plan were intended to raise the productivity of African farms by improving farming methods and intensifying the raising of crops. The plan called for the recognition and encouragement of the evolution from communal to individual land tenure. In the meantime, the Colonial Office had recommended the appointment of a Royal Commission and on January 1st, 1953, a Royal Warrant was issued, the preamble to which read as follows:

"Whereas, having regard to the rapid rate of increase of the African population of East Africa and the congestion of the population on the land in certain localities, We have deemed it expedient that a Commission should forthwith examine the measures necessary to be taken to achieve an improved standard of living, including the introduction of capital to enable peasant farming to develop and expand production; and frame recommendations thereon with particular reference to:

1) the economic development of the land already in occupation by the introduction of better farming methods;

2) the adaptations or modifications in traditional tribal systems of tenure necessary for the full development of the land; ...”

At the time of the setting up the East Africa Royal Commission, the tenurial system was a dual one, with an English real property type of landholding, based largely on the Indian Transfer of Property Act, 1882 and a system of registration of title based on the Torrens system on the one hand and customary law systems of tenure on the other.

The land was divided into Native Lands which were administered according to the Native Lands Trust Ordinance ${ }^{7}$, and Crown Land which was governed by the Crown Lands Ordinance ${ }^{8}$. Native Lands were vested in a Native Lands Trust Board which held the areas comprised in each unit in trust for the native tribes ordinarily resident in those areas. Land in the Native Trust areas was held under customary law. The Crown Lands Ordinance made provision for the following categories of Crown Land; Native Reserves, Temporary Native Reserves, Native Settlement Areas, Communal Reserves, the Highlands, the Northern Frontier District, the Turkana District and Crown Land not falling within any of these categories. In the Native Land Units and in all categories of Crown Lands, with the exception of the Highlands and the residual Crown Lands, some specific race or tribe was given an exclusive interest in the land. In the Highlands, the land was under the control of the Highlands Board and although it did not have legal power to prevent the holding of land in the Highlands by non-Europeans, each transaction in land required the consent of the Governor and in every lease granted to a European in the Highlands there was an implied covenant that he should not, without the consent of the Governor-in-Council, appoint or allow a non-European to be manager or otherwise to occupy or be in control of the land leased.

This was the background against which the East Africa Royal Commission set to work. The Commission reported in 1955 and its report proved a turning

6 A Plan to Intensify the Development of African Agriculture in Kenya (1954).

7 1930, subsequently the Trust Land Act (Cap. 288).

8 1915, subsequently the Government Lands Act (Cap. 280). 
point in the development of land tenure in East Africa. The report called for a complete economic re-orientation, for a change from a subsistence economy and subsistence farming to a commercial agricultural system. In order to achieve this change, the report called for a policy on land tenure which should aim at the individualisation of land ownership and mobility in the transfer of land which would enable access to land for economic use ${ }^{9}$. The Commission recommended that land tenure law should not be left to evolve under the impact of modern influences but that a lead must be given by governments to meet the requirements of the progressive elements of society by applying a more satisfactory land tenure system ${ }^{10}$.

The Commission approached their task in an admirable way; they had looked at the advantages and the disadvantages of the existing system and considered alternative methods of remedying defects. In the body of the Report, it is clear that a great deal of objective thinking took place and that the Commission's nembers did not appear to be starting work with preconceived ideas as to what might be their ultimate conclusions. It is perhaps regretful that after all their painstaking efforts, their final recommendations do not make it clear that they considered any alternative to individualisation of land ownership, in spite of the many dangers which they themselves foresaw in such a change in the existing tenure. For example, in discussing the advantages and disadvantages of a land tenure system based on individualisation of title, the report reads:

". . . evidence from East Africa itself is not always reassuring when those areas where individual tenure has proceeded furthest are examined. While undoubtedly, some farmers in Buganda and Kikuyu have shown considerable interest in good land usage, others show that the acquisition of land for prestige, or purely for speculation, or for crop mining, is at least an equal probability arising out of grants of individual tenure... Neither individual tenure nor co-operatives nor collective farming necessarily make crops grow better ${ }^{11} . "$

and again:

"Elsewhere the individual ownership of land in peasant communities has sometimes led to the emergence of a chronic state of indebtedness, the continued fragmentation of holdings and the unproductive accumulation and holding of land by a few individuals in circumstances of little alternative income-earning opportunity for those who have parted with their land ${ }^{12}$."

In fact, most of the problems evisaged by the Commission have arisen, to a greater or lesser extent in Kenya and some have had to be tackled by later legislation. In 1956, the Kenya Government annouced its acceptance of the Commission's Report and stated that is was the policy of the Government to encourage the emergence of individual land tenure among Africans where conditions were ripe for it and in due course, to institute a system of registration of negotiable title.

9 East Africa Royal Commission 1953-55 Report, p. 428.

10 East Africa Royal Commission 1953-55 Report, p. 428.

11 Ibid. p. 324

12 Ibid. p. 355 


\section{Land Reform Programme}

The East Africa Royal Commission recommended that individual rights of land ownership should be confirmed by a process of adjudication and registration. Legislation should be enacted which would empower the government to dispose of all residual interests in land, particularly to individuals already holding interests in land not amounting to ownership ${ }^{13}$. The first legislation to be enacted to put the recommendations of the Commission into effect were the Native Land Tenure Rules, 1956, promulgated under the Native Lands Trust Ordinance, 1938. Under these rules, the claim of an individual to a piece of land was adjudicated upon in order to ascertain what his entitlement was; in cases where one person was found to hold scattered fragments of land of uneconomic size, he was allocated, from a planned lay-out, a single plot of land equivalent to the aggregate of the plots to which he had been found entitled. This is the process of adjudication and consolidation which has been extended and improved upon for the past decade and a half in Kenya.

Consolidation was defined as "those measures which are designed to remedy two distinct coditions; the division of rural property into undersized units

two distinct conditions; the division of rural property into undersized units unfit for rational exploitation, and the excessive dispersion of the parcels forming parts of one farm"14. The former condition is conveniently referred to as "sub-division" and the latter as "fragmentation". Consolidation consists of re-planning the proprietary land units within a given area and re-distributing them in units of economic size and shape.

In such a planning exercise, two situations may arise. The first is where each of the proprietors holds several fragments of land in the same area and it is possible to aggregate these fragments and then redistribute the land so that the holding of each proprietor, instead of being dispersed, is consolidated into one holding of economic size and shape. The second situation is where there are as many proprietors as there are fragments of land. This is the "sub-division" situation referred to above. In this situation, the redistribution of land in larger and more economic holdings means that some proprietors must give up their land and look for alternative sources of livelihood within the same area or move to another area where land is available ${ }^{15}$. The legislation framed to effect the land reform programme in Kenya was intended to remedy only the first of the problem situations mentioned above; however, this type of local re-distribution of land could not overcome the problem of over-population in certain localities for which the second remedy mentioned was the only solution. The second type of consolidation involves a measure of expropriation of land and the eviction of persons already on the land. The first remedy may cure fragmentation but it cannot cure uneconomic sub-division.

"Adjudication is the means by which a final ascertainment is made of existing rights in land. Its cardinal principle is that it recognizes and confirms rights which are actually in being; it does not alter or create rights, though it may substitute a right defined under statute for what it considers to be its equivalent

13 East Africa Royal Commission 1953-55 Report, p. 428

14 F. A. O. Legislative Series No. 3 Principles of Land Consolidation Legislation.

15 Report of the Mission on Land Consolidation and Registration in Kenya, 1965-66, p. 7. 
under customary law ${ }^{16}$. One criticism which could be made and has been made of this concept is that it does not regard adjudication as altering a right. This may have been the intention of the legislation promulgated to set up the processes of adjudication but it is much more difficult to recognize and confirm the equivalent of a customary law right than perhaps was realized by those recommending the process. Adjudication was followed by registration of the title of the interest holder and writing on the limitations of registration of title in Africa, Professor A. N. Allott says:

"Registration demands a defined parcel over which registered rights may be exercised. Many customary laws do not proceed by way of fixed, determined boundaries. It is not only in respect of so-called shifting cultivation that this point applies, though clearly there the contrast is most pronounced; even welldefined agricultural rights, e. g. to make a cocoa farm out of a virgin forest, in respect of a defined area, may carry the legal implication of a priority claim to take up a certain amount of the unoccupied land lying in the path of advance of the cultivator" 17 .

How is such an interest to be defined on adjudication? Is there an equivalence in statutory law terms? Professor Allot also discusses the problem which arises in distinguishing between the customary law interests of benefit and those of control or mixed benefit and control. Often the customary system of land control is superseded by control through land boards. This may be the only realistic method of dealing with the transition from a customary to a statutory system of land tenure but it is misleading to assume that the process of adjudication of claims in Kenya has not and will not alter existing rights; in some cases, it creates rights which had no former recognition or equivalence in customary tenure, e. g. the holding of family land in divisible shares, and extinguishes rights which formerly existed.

The Land Adjudication Ordinance, 1959, (Cap. 283) provided for the ascertainment and recording of rights and interests in land, for the consolidation and demarcation of land and for the creation of an adjudication register. Registration of rights then proceeded under the Land Registration (Special Areas) Ordinance, 1959. The system of registration set out in the Land Registration (Special Areas) Ordinance was based on the system of registration then operating in the Sudan. This Ordinance has been superseded by the Registered Land Act, 1963 (Cap. 300) which is intended eventually to apply to the whole of the country.

Adjudication and consolidation procedures were carried out by an Adjudication Officer, appointed by the Minister for Lands and assisted by a Committee appointed from amongst persons resident in the adjudication area to which the Ordinance had been applied. The Committee normally consisted of the elders for the locality and its main purpose was to ensure, through its local knowledge, that claims under the customary law were given due recognition ${ }^{18}$. Claimants were required to attend before the Committee on a day specified by the Adjudication Officer. The Adjudication Officer was required to give notice of the declaration of any areas as one or more adjudication section and to fix a period, which had to be not less than six months, within which any individual

\footnotetext{
16 Ibid. p. 36. aneoretical and Practical Limitations to Registration of Title in Tropical Africa, Paper presented to a Seminar of Land Tenure in African Development, Afrika-Studiecentrum, Leiden, 1971.

18 (Cap. 283), s. 9.
} 
claiming any right or interest in any land within the section was required to present his claim to the Committee ${ }^{19}$. The Committee adjudicated upon and determined in accordance with native law and custom, the claim of any individual person to any right or interest in any land within the adjudication section and if it was unable to reach a decision, it was required to refer the matter to an Arbitration Board set up under the Ordinance ${ }^{20}$. The Ordinance set up a Record of Existing Rights in which was entered "the name and description of every person whose right should be recognized as ownership, together with a description of every parcel of land to which he is entitled"21. Any person named in or affected by the Record of Existing Rights could raise an objection within 60 days of the Record being laid open for inspection ${ }^{22}$. The Committee and the Arbitration Board might be consulted in regard to objections but the final decision was taken by the Adjudication Officer, who might approve or amend the Record accordingly ${ }^{23}$.

Powers to set aside land out of the land in the adjudication section were given to the Committee under section 21; the Committee might expropriate land in order to effect consolidation and any landowner detrimentally affected by being required to relinquish his landholding might be compensated in money or in kind. Perhaps one of the most striking features of this legislation is the immense power given to Adjudication Officers and the complete absence of any provision for the settlement of any disputed claim to titlc by a court of law. The final decision is an administrative one. The only intervention by the Court is when an application has been made for rectification of an Adjudication Register and the Adjudication Officer has decided to award compensation in lieu of rectification. In such a case, any person to whom compensation has been awarded and who is dissatisfied with the amount, may apply to a subordinate court held by a Resident Magistrate for a revision of the award 24.

Whenever an Adjudication Register has become final, it is delivered to the Lands Registrar for the district and forms part of the register of titles now set up under the Registered Land Act, (300) but formerly governed by the provisions of the Land Registration (Special Areas) Ordinance, 1959. When the Special Areas Ordinance was repealed in 1963, by the Registered Land Act, a new and efficient system of registration of titles was introduced and those titles formerly held under various existing forms of registration were brought on to the new register set up under the Registered Land Act. Under section 11 of the Registered Land Act, when an adjudication register has been delivered to him, the Registrar is charged with preparing a register for each person shown in the adjudication register as a landowner and every other person shown as being entitled to the benefit of any interest, lease, right of occupation, charge or other encumbrance affecting the land. For the purposes of the Act, a right of occupation under African customary law, recorded in the adjudication register is deemed to be a tenancy from year to year. It is difficult to imagine why it was necessary to equate a right of occupancy with a tenancy from year to year; it would have seemed more logical and simpler to register it as a right of occupancy.




The effect of registration under the Registered Land Act is that the person registered as proprietor of the land becomes the absolute owner of that land together with all the rights and privileges belonging to the land ${ }^{25}$. The customary law interests which are recorded as less than proprietorship or are not recorded, as tenancies from year, fall within section 30 .

This section provides that all registered land, unless the contrary is expressed in the register, shall be subject to the overriding interests set out in the section. These include rights of occupation, rights of way and of water and profits.

\section{Review of the Reforms}

In 1965, the Kenya Government requested assistance from the British Government for a broad programme of agricultural development and one of the major objectives of this programme was stated to be "a basic reform in the tribal system of land tenure, to be accomplished through an acceleration of the process of land consolidation and registration'. The Mission on Land Consolidation and Registration in Kenya ${ }^{26}$ reported in 1966 after having spent six months on an intensive study of the operation and effects of the adjudication, consolidation and registration processes in Kenya. Ten years had elapsed since the recommendations of the East Africa Royal Commission Report had been accepted and in that time, 1,630,597 acres had been brought on to the register in 274,582 separate parcels of land ${ }^{27}$.

The costs involved were set out under three separate headings, viz. (a) survey costs, (b) land adjudication costs and (c) registry costs. The Mission found that the approximate total expenditure on the programme from 1956 to the end of the year was as follows:

\begin{tabular}{lc} 
& $£$ \\
Survey & $1,287,577$ \\
Adjudication & $1,995,437$ \\
Registry & 69,000 \\
\hline & $3,352,014$
\end{tabular}

The estimated costs of accelerating the programme as recommended by the Mission for the four years from 1966-70 were:

\begin{tabular}{lc} 
& $£$ \\
Survey & 996,755 \\
Adjudication & $2,814,166$ \\
Registry & 70,658 \\
\hline & $3,881,579^{28}$
\end{tabular}

The four-year total acreage to be adjudicated and registered was 2,696,000 acres.

In its consideration of the circumstances in which such a programme of adjudication and registration might not be applicable, the Mission in its Report stated:

25 s. 27

26 The members of the Mission were Mr. J. C. D. Lawrence (Chairman), Mr. G. J. Humphries, Mr. S. R. Simpson, Mr. G. M. Gaitta, Mr. C. P. R. Nottidge and Mr. J. D. MacArthur.

27 Report of the Mission on Land Consolidation and Registration in Kenya, 1965-66, p. 10.

28 Ibid., p. 118, Table 16. 
"The Kenya Government has hitherto used the process of adjudication in the former Special Areas for the purpose of confirming individual ownership where equivalent rights already subsist, or of conferring such rights where they do not. This is precisely what the East Africa Royal Commission recommended and we have no doubt that it is sound policy, but sometimes, individual ownership can be an impediment to development ...29."

The Mission went on to point out that in several areas, for various reasons, some form of communal holding was more beneficial to the effective use and development of the land than adjudication leading to the registration of titles in indivudual ownership. For example, in some semi-arid areas of the country, it was considered harmful to register in individual ownership, land which was badly eroded or denuded of grass cover, for the owners might not be able to subsist on their holdings. Such land was much more easily brought within the remedial section of an agricultural improvement plan if the whole locality could be treated as one holding.

The warning given by the East Africa Royal Commission in 1956 in regard to the need to protect unsophisticated landowners against unproductive indebtedness had not been effectively heeded in the land control legislation already in existence and the Mission recommended a new Land Control Act ${ }^{30}$. The Mission considered the vexed problem of refragmentation and subdivisions below the economic minimum and the extent to which further legislation or a new procedure was required to prevent its recurrence. In some countries attempts have been made to fix an economic minimum acreage which should be operated through the registry procedure. However, it was recognised that as the register shows ownership of land rather than use of land, this could be quite misleading when economic considerations, population pressures and the continuing application of the customary law of succession to land holdings led to subdivision of the land which was not necessarily reflected in the register. This has been a problem in many other countries into which systems of registration, either with or without consolidation have been introduced e. g. the Buganda district of Uganda.

To relieve these and some further problems which they found to exist, the Mission recommended a series of new Acts of Parliament and several important amendments to existing Acts. As a result, a new Land Adjudication Act, 1968 was passed, which incorporated a simpler form of surveying and separated the functions of consolidation and adjudication. The former Land Adjudication was renamed the Land Consolidation Act (Cap. 283). The new Land Adjudication Act dealt with the recommendation that some form of group ownership should be recognised and provided:

„23 (2) In preparing the adjudication record, the recording officer, if he is satisfied that -

a) any person has, under recognised customary law, exercised rights in or over land which should be recognised as ownership, shall determine that person to be the owner of that land:

Provided that if -

i) the land adjoins land of which a group is determined under paragraph (b) of this subsection to be the owner; and

29 Report of the Mission on Land Consolidation and Registration, p. 34 30 Ibid. p. 82. 
ii) that person desires to join the group and to have his land added to the group's land; and

iii) the group is willing to have that person as a member.

The recording officer shall determine that group to be the owner of that land, and thereupon, that person shall become a nember of that group.

b) any group has, under recognised customary law, exercised rights in or over land which should be recognised as ownership, shall determine that group to be the owner of that land. ...”

Perhaps the most interesting point which arises from these subsections is that once the recording officer has accepted that the claimant's land adjoins that of the group and the group agrees to have him as a nember, the determination by the recording officer that the claimant's land belongs to the group has the effect of bringing the claimant within the group nembership. This is a new method of creating a customary law interest or a bundle of interests. It is not clear at this stage what the new nember's rights will be within the group itself. Membership of a "group" in customary law, entails other and very different interests and rights from those set out in the Acts. Is the new member a "full" group member and what is the nature of his interest?

Section 23 goes on to provide that if two or more persons are recorded as the owners of land or entitled to an interest not amounting to ownership of land, the adjudication officer shall determine and record whether they own or are entitled jointly or in common and in the latter case, the shares of each. This is an interesting usage of English real property terms to describe or equate customary law interests. Such a usage is fraught with anomalies; no possible equivalence between the systems can be reached but the only other realistic approach would have been to invent new terms which might equally well not have adequately described the nature of the interests to which they referred. As long as there is no rigid adherence to a strictly English interpretation of the "equivalent" terms used, no great difficulty should arise.

To complete the recognition of group ownership, and to provide for the continuing control of the land by the group, a further Act, the Land (Group Representatives) Act, 1968 was passed. The Act provided for the incorporation and registration of groups on a special register of group representatives and laid down a form of constitution which each group must adopt. Procedures for the election and meeting of representatives were prescribed. The procedure for the control of the land holding is more reminiscent of the functioning of a co-operative society than of a typical African family group. However, once more, it is easy to criticize such a provision but much more difficult to put forward a workable alternative formula. Perhaps in this instance too, a degree of flexibility in the application of the provisions of the Act is required and a watering down of the excessively formalistic terminology used in framing the processes.

Another interesting point in the Act is the definition of a group in section 2 as a "tribe, clan, section, family or other group of persons whose land under recognized customary law belongs communally to the persons who are, for the time being, members of the group, together with any person whose land the group is determined to be the owner under the proviso to section 23 (2) of this Act". The definition does not extend to statutory groups such as co-operative 
societies or registered companies who are already corporate bodies under the Cooperative Scoieties Act or the Companies Act respectively and can be registered as proprietors of the society's or company's land under the Registered Land Act.

The Registered Land Act (Lagos), 1965 contained provisions for the registration of family interests in land which provide an interesting contrast to those in the Land (Group Representatives) Act. Section 11 (3) of the Lagos Act gave a registration officer power to (a) register the names of all members of the family who are entitled to a share therein, together with the size of the share of each member; or, if the number of members of a family exceeds twenty, or the majority of such members so requests, register the name of the family and the names of the representatives of the family who are to have the exclusive rights and powers and be the registered proprietors for the purposes of any dealing with the land. A procedure for ascertaining the family representatives is laid down under the Act. The Lagos Act has never been brought into force but one of the main criticisms which could be made of its provisions is that there is an assumption in section 11 that family land is held on the basis of divisible shares; there is an equating of the interest held by family with that of the English real property interest of common ownership. This type of ownership is incompatible with recognised concepts of customary law. In the Land (Group Representatives) Act of Kenya, an attempt has been made to overcome this anomaly by making the provision wide enough to cover both an interest in divisible and an interest in indivisible shares ${ }^{31}$. Whether either is an accurate decsription of a family or group member's interest in family or group land under customary law is a matter of some doubt.

The control of land use has been re-examined in accordance with the recommendations of the Mission and a new Land Control Act has been passed ${ }^{32}$. The Act renders void any transaction in land which has not received the consent of a Land Control Board within three months from the date of entering into the transaction ${ }^{33}$. Land Control Boards are appointed by the Minister for Lands and Settlement and consist of the District Commissioner for the area, not more than two other public officers, two persons nominated by the local county council and not less than three nor more than seven persons resident within the area ${ }^{34}$.

Appeals from the decisions of Land. Control Boards are to a Provincial Land Control Appeals Board and finally to a Central Land Control Appeals Board. At all levels, the Boards are under the control of the Minister and are administrative bodies; in the Central Land Control Appeals Board, the Minister is the Chairman and the Attorney General a member. No appeal lies from their decisions to a court of law. The President has the right, under s. 24 and s. 25 of the Act to prohibit or to exempt any controlled transaction from the provisions of the Act.

The principles on which a Land Control Board shall give or refuse consent to a transaction are laid down in section 9 of the Act. A board is required to have regard to the effect which the grant or refusal of consent is likely to have on the

31 supra. p. 59.

32 (Cap. 302)

33 Ibid. s. 6

34 Schedule to the Act. 
economic development of the land concerned or in the maintenance or improvement of standards of good husbandry within the area.

The board is to act on the principle that consent to the transfer of land ought normally to be refused where the person who is to take over the land is unlikely to farm it well or develop it adequately. Again, consent should be refused if the person to whom the land is to be transferred already has sufficient agricultural land or the terms and conditions of the transaction (including the price to be paid) are markedly unfair or disadvantageous to one of the parties to the transaction. These latter provisions amount to a sweeping away of the former common law concept of freedom of contract, not by a court of law, but by an administrative body.

The board must refuse its consent in any case in which the person to whom the land is to be transferred is not a citizen of Kenya or is not a private company or a co-operative society all of whose members are citizens of Kenya. These provisions are understandable and eminently justifiable in an independent African country. One observation, however, in regard to the latter part of the provision, viz. where the prospective transferee is a non-citizen company; in this situation, the legislature has seen fit to ignore the general principle of company law that the indentity of a company is distinct and separate from that of the individuals who constitute its members. This is not a unique departure from the general rule; the commonest examples being cases under the income tax legislation. In most cases, the reasons given for departing from the rule have been that to follow the rule would not be in the national interest. The plea of national interest could no doubt be supported in regard to transfers of land to non-citizen companies.

The Act applies to agricultural land; all other land is controlled under the new Land Planning Act, 1968 and the Town Planning Act (Cap. 134). Further control over the use of land is set out in the Agriculture Act ${ }^{35}$. The Minister for Agriculture is given power to make regulations which may impose development conditions on any lands specified in the order ${ }^{36}$. The Minister may require the owner or occupier or both, to submit a programme of development of the land to the District Agricultural Board. The owner or occupier of the land may be required to take certain actions to preserve his land or he may be ordered to refrain from taking action which might in the opinion of the Minister, have a detrimental effect on the land. If an order to preserve land is made against an owner or occupier, a note is made against the title to the land in the Register of Titles ${ }^{37}$. An owner occupier may be dispossessed of his land if the Minister is satisfied that the land has either ceased to be managed or is being inadequately managed ${ }^{38}$. The holding is then occupied by the Minister, who may lease or sell the land, after due notice to the owner. Although the proceeds of the sale of the land must be paid to the owner, or compensation paid to him for any loss he may have suffered due to the making of the order, the provision is still a very serious diminution of the principle of freedom to property. Although the need for strict control over the development and use of land is essential to Kenya's national interest, the placing of such a powerful weapon of control in the hands of administrators is not something to be undertaken lightly.

35 (cap. 318).

36 s. 64.

37 (Cap. 318), s. 56

38 Ibid. s. 187. 


\section{Conclusions}

The Kenya land reform programme has been systematically implemented and reviewed. Where it has been found to be inadequate or giving rise to problems, it has been revised with a view to alleviating the difficulties. It is now sufficiently advanced for an evaluation of its success to be attempted. In this article we are concerned only with the general problems which have arisen rather than with the more specific, so that we may consider the value of the programme as a model for other African countries.

1. Technically, as a programme to reform a pluralistic land tenure system in a country with a mixed economy, the present legislation is well-devised. Perhaps the definitions of the types of ownership, proprietorship and interests could well be rationalised and more thought given to their equivalence to customary law. There are conflicts between the Land Adjudication Act, the Registered Land Act and the Land (Group Representatives) Act which could well be reconciled. The procedures laid down in the Land (Group Representatives) Act for the control of and dealings in land are too rigid and complex to be assimilated to family or tribal customs. However, these are all amendments which could easily be made without changing radically the nature of the legislation.

2. Administratively, it is perhaps unfortunate that no fixed limit has been set on the amount of land which may be held by one individual. This is a matter of policy; the power to control the acquisition of further land by an individual already holding large tracts is already included in the provisions of the Land Control Act ${ }^{39}$. However, there is little evidence that Land Control Boards are imposing any very strict limit on the maximum holding which they consider should be allowed. It is perhaps a just criticism of the Kenya system that too much land is still being accumulated in the hands of acquisitive individuals and that the gap between the "haves" and the "have-nots" is being widened rather than narrowed. In 1958, J. Nyerere, later to become President Nyerere of the Republic of Tanzania said ${ }^{40}$ :

"In a country such as this where, generally speaking, the Africans are poor and the foreigners are rich, it is quite possible that, within eighty or a hundred years, if the poor African were allowed to sell his land, all the land in Tanganyika would belong to the wealthy immigrants, and the local people would be tenants. But even if there were no rich foreigners in this country, there would emerge rich and clever Tanganyikans. If we allow land to be sold like a robe, within a short period there would only be a few Africans possessing land in Tanganyika and all the others would be tenants." A system such as the Kenya system has the inherent danger of too much power being vested in the hands of administrators. This can only be guarded against by making sure that rights of appeal to a court of law against an administrative decision are inserted in the legislation. For example, a right of appeal to the court against the decision of an Adjudication Committee under the Adjudication Act would be desirable.

3. Any country which seeks to emulate the Kenya-type land tenure reforms will have to take certain policy decisions. The system of consolidation, adjudication and registration introduced in Kenya is equally well-suited to a land tenure 
system based on the concept of individual ownership of land or on a communal form of land holding. The emphasis might well be different; after all, the Kenya system was originally intended to provide only for the registration of individual titles to land. The system was easily adapted when it was found desirable to provide for the registration of a communal form of holding.

Again, if the political and economic structure of the country concerned calls for State ownership of land, the Kenya system could be used, allied to a different concept of the type of interest to be registered. For example, in a country with a land tenure system based on leasehold or a right of occupancy, the only basic amendment would be in regard to the nature of the interest to be conferred by registration.

4. To set up and administer such a system efficiently and well requires financing. We have quoted a figure of approximaterly $71 / 2$ million pounds Kenyan to register an acreage of approximately $4 \frac{1}{2}$ millions acres. That is an approximation of shs. 33.00 per acre. 


\title{
Bills of Rights in "The Third World": Some Commonwealth Experiences
}

\author{
By James S. Read
}

The constitutions of the majority of the thirty-two independent states of the Commonwealth include enforceable "bills of rights"; such provisions were adopted, contrary to British constitutional tradition, in almos all of the "new states" of Africa, the Mediterranean, Caribbean and Pacific which became independent of British rule in the 1960s, but the oldest Commonwealth example is found in the lately independent Kingdom of Tonga, where the Constitution dates from 1875. Most of the "bills of rights" are in very similar terms, following the Nigerian model which was itself based upon the European Convention on Human Rights. Some British dependencies, and the autonomous "associated states" of the Caribbean, also have bills of rights. It may, however, be questioned whether the constitutional guarantees of fundamental rights are appropriate or realistic in the "third world" where economic, social and political problems are generally pressing; yet Commonwealth states generally have preserved these forms of protection for individuals despite constitutional changes or upheavals (sometimes even under military government) - perhaps because, with the exception of India, the guarantees, although justiciable, are seldom invoked in the courts. Nevertheless it is difficult to see these provisions as being deeply rooted either in the traditional political structure or in the recent colonial experience of the local communities concerned. Tanzania has rejected this mode of protecting human rights, preferring an active and effective type of "Ombudsman". The Commonwealth pattern of bills of rights, while far-reaching in substantive provisions, includes a number of qualifications and exceptions which limit their applicability. The judicial response, in the small number of reported cases (which are reviewed), has been mainly a cautious one although legislation and executive action has been invalidated in some states, particularly under the prohibition of discrimination. (India, where there is much litigation on the bill of rights, is not included in this study.) Generally the courts have preferred a literal to a liberal interpretation. In the application of a selfimposed "presumption of constitutionality", where legislation is impugned, courts in the Commonwealth appear to be emulating the caution of the European Commission of Human Rights when it invokes the "margin of appreciation" doctrine.

\section{The Kenya Land law reform programme A Model for Modern Africa?}

\section{By Margaret A. Rogers}

The need for reform of their land tenure systems is high on the list of priorities of most independent African countries and is largely due to their inheriting a dual system of land law from the superimposition of a colonial land law system upon their own indigenous law. Kenya has undertaken a radical land law reform programme and as this was first put into operation in the mid-nineteen fifties and reviewed and modified in the late nineteen sixties, it makes an ideal study of how the many problems which are common to most African countries which have 
inherited an anglo-based legal system should or perhaps, should not, be tackled. Some of the present day problems in regard to land policy arose out of the strains and tensions imposed by the indigenous customs in regard to succession to land and the practice of a shifting agriculture system; these problems were aggravated by the colonial administration and the allocation of land to European settlers. The British Colonial Office set up a Commission in 1953 to review the land problems and recommend reforms. These reforms were accepted and put into effect by the Kenya Government from 1959-1963. They gave rise to some problems and the position was again reviewed in 1966 when further reforms were recommended. The reforms are based on the adjudication and consolidation of land titles coupled to a system of registration. An attempt has been made to apply the reforms to land held under customary tenure as well as that held under the colonial system of law and although problems have arisen, the Kenya Government is determined to tackle these in a progressive manner.

\section{Socio-Economic Change and Constitutional Reform in Chile, 1925-1972}

\section{By Dieter Nohlen}

Since $1810 / 1817$, the exceptionally stable system of constitutional government in Chile has produced only two constitutions: those of 1833 and 1925, and a high degree of legitimacy. Traditional institutions were democracized along Western lines. They gradually integrated different social strata, allowing political parties to take roots in the social fabric as an element of political stability. The 19th century political parties remained dominant for about 100 years. In contrast to the political, i. e. institutional evolution, social and economic development lagged behind. The Popular Front presidency in the late thirties, however, put new accents on industrialization and social change such as increase in population and urbanization. When private sectors could not cope with these problems the State seized control over economic development by promoting, financing and managing industrial activities. But the general situation even deteriorated, given the maintenance of oligarchical and obsolete structures. Hence, internal polarization and dependency as signs of underdevelopment increased (Chapt. I). Against this socio-economic background emerged the modern political parties (Christian-Democratic, Communist and Socialist). They initiated an overall mobilization and urged structural reforms in economy and society. Both the Christian-Democratic and Marxist programs, competing in the 1964 presidential election, called for reform of the 1925 constitution (Chapt. II). Within the framework of representative democracy Eduardo Frei initiated and partly achieved extensive reforms with the aim of modernizing economic, social and political institutions and procedures (Chapt. III). His successor, Salvador Allende, head of a coalition government with Marxist parties in dominant position, sought to fundamentally change the political system into a socialist society. Christian Democrats demanded constitutional guarantees concerning civil liberties and pluralistic democracy. Allende had to agree in order to get Christian-Democratic votes necessary to obtain the absolute majority during the second election round in Congress (Chapt. IV). Allende obtained the constitutional change allowing the nationalization of mines and foreign companies exploiting copper by unanimous vote. His attempts gradually to create a socialist system, 